\title{
EHMTI-0098. Frontal executive functions in medication overuse headache
}

\author{
HA Sahin ${ }^{1 *}, Y$ Turkel $^{1}$, EO Sahin ${ }^{2}$, T Ozbenli ${ }^{3}$ \\ From 4th European Headache and Migraine Trust International Congress: EHMTIC 2014 \\ Copenhagen, Denmark. 18-21 September 2014
}

\section{Introduction}

In the neuroimaging studies, prefrontal dysfunctions have been reported in the patients with medication overuse headache $(\mathrm{MOH})$.

\section{Aims}

The study investigates the presence of cognitive deficits in patients with medication overuse headache $(\mathrm{MOH})$ or migraine without aura as compared to healthy controls.

\section{Methods}

Neuropsychological test battery assessing frontal executive functions and attention was applied in 50 patients with $\mathrm{MOH}, 50$ patients with migraine without aura and 50 control subjects. Depressive symptoms were measured with Hamilton depression rating scale.

\section{Results}

The results were compared between the three groups using analysis of covariance. Tukey test was used for post hoc multiple comparisons. The patients with $\mathrm{MOH}$ performed worse than patients with migraine on the digit span-forward, digit span-backward, verbal fluency KAS, animal numbers in attention and total categories completed on WCST, TMT A-B, total number of errors on $\mathrm{CPT}$ in executive functions whereas they were worsen than the control subjects on almost all tests. The patients with migraine were significantly poorer than control subjects on digit span-backward, and showed higher number of perseverating responses on WCST, total number of errors on CPT, and total number of errors on Go-NoGo.

\section{Conclusions}

The patients with MOH have frontal dysexecutive syndrome characterized by an inability in the inhibition of

${ }^{1}$ Neurology, Ondokuz Mayis University Faculty of Medicine, Samsun, Turkey Full list of author information is available at the end of the article inappropriate responses and attention deficit. There are studies suggesting an association between drug addiction behavior and $\mathrm{MOH}$ via prefrontal cortex involvement. Our results further support the notion that $\mathrm{MOH}$ may be a part of the spectrum of drug addiction behavior.

No conflict of interest.

\section{Authors' details}

'Neurology, Ondokuz Mayis University Faculty of Medicine, Samsun, Turkey. ${ }^{2}$ Neurology, Education ve Research Hospital, Samsun, Turkey. ${ }^{3}$ Neurology, Ondokuz Mayis University Faculty of Medicine, Samsun, Turkey.

Published: 18 September 2014

\section{doi:10.1186/1129-2377-15-S1-C48}

Cite this article as: Sahin et al:: EHMTI-0098. Frontal executive functions in medication overuse headache. The Journal of Headache and Pain 2014 15(Suppl 1):C48.

\section{SpringerOpen $^{\circ}$}

C 2014 Sahin et al; licensee Springer. This is an Open Access article distributed under the terms of the Creative Commons Attribution License (http://creativecommons.org/licenses/by/2.0), which permits unrestricted use, distribution, and reproduction in any medium, provided the original work is properly cited.
Submit your manuscript to a SpringerOpen ${ }^{\circ}$ journal and benefit from:

- Convenient online submission

- Rigorous peer review

- Immediate publication on acceptance

- Open access: articles freely available online

- High visibility within the field

- Retaining the copyright to your article

Submit your next manuscript at springeropen.com 